\title{
$\mathrm{CoFe}_{2} \mathrm{O}_{4} /$ CHITOSAN MAGNETIC NANOCOMPOSITE:
}

\section{SYNTHESIS, CHARACTERIZATION AND APPLICATION FOR ADSORPTION OF ACIDIC YELLOW DYE FROM AQUEOUS SOLUTIONS}

\author{
HAMIDREZA ANSARI, MAHSASADAT MIRALINAGHI and FARIBORZ AZIZINEZHAD \\ Department of Chemistry, Faculty of Science, Islamic Azad University, Varamin-Pishva Branch, \\ P.O. Box 33817-7489, Varamin, Iran \\ ×Corresponding author: M. Miralinaghi,m_miralinaghi@iauvaramin.ac.ir
}

Received July 7, 2018

\begin{abstract}
Magnetic chitosan-modified $\mathrm{CoFe}_{2} \mathrm{O}_{4}$ nanoparticles, $\mathrm{CS} / \mathrm{CoFe}_{2} \mathrm{O}_{4}$, were successfully synthesized by an in situ coprecipitation technique. The structure, crystal phase, surface morphology and magnetic properties of $\mathrm{CS} / \mathrm{CoFe} \mathrm{O}_{4}$ were characterized by FTIR, TGA, XRD, FE-SEM, EDX and VSM analyses. The as-prepared $\mathrm{CS} / \mathrm{CoFe} \mathrm{O}_{4}$ nanoparticles were employed to adsorb Acid Yellow 17 dye (AY17) from aqueous solutions. The influence of experimental parameters, such as $\mathrm{pH}$, temperature, contact time, adsorbent dosage and initial dye concentration on the efficiency of AY17 adsorption was studied. The maximum dye removal percentage reached $90 \%$ after 90 min adsorption at $\mathrm{pH} 4.0$ and $323 \mathrm{~K}$ for the solution with an initial AY17 concentration of $30 \mathrm{mg} \mathrm{L}^{-1}$ and CS/CoFe $\mathrm{O}_{4}$ dose of $0.01 \mathrm{~g}$. The adsorption kinetics agreed well with the pseudo-second order model. The isothermal data preferably followed the Langmuir model, with the maximum adsorption capacity of $89.10 \mathrm{mg} \mathrm{g}^{-1}$. Thermodynamic studies illustrated that the adsorption process is endothermic and spontaneous.
\end{abstract}

Keywords: Acid yellow, adsorption, chitosan, dye, removal

\section{INTRODUCTION}

Dyes are colored organic compounds, extensively used to impart color to raw materials and applied in the production of leather, paper, pharmaceuticals, foods, cosmetics, plastics, textiles etc. ${ }^{1}$ More than 10000 tons of dye are annually used only in the textile industry worldwide and almost 100 tons of dyes are discharged into waste streams per year. ${ }^{2}$ A huge number of industrial dyes are highly toxic, carcinogenic and mutagenic, even at relatively low concentrations, causing serious environmental hazards and severe damage to humans. The removal of dyes from effluents plays a crucial role in controlling water pollution and conserving aquatic ecosystems. ${ }^{3}$ Among the range of techniques available for dye removal from effluents, adsorption is recognized as a simple, efficient and economical technique used for wastewater treatment, especially in less developed countries. Undoubtedly, due to its high porosity and huge surface area $\left(200-500 \mathrm{~m}^{2} \mathrm{~g}^{-1}\right)$, active carbon is the most common adsorbent applied in dye adsorption, but its high cost and low regeneration limit its application. Therefore, further research is necessary to develop novel absorbents that are economically cost-effective and environmentally friendly, besides being capable of removing a huge amount of pollutants, and being easily and rapidly recovered. ${ }^{4,5}$

Due to their high number of surface-active sites, fast removal rates and easy magnetic recovery, magnetic nanoparticles have emerged as promising absorbents, compared to traditional ones. ${ }^{6,7}$ However, magnetic nanoparticles are chemically highly active and easily oxidized in the air, affecting the long-term magnetic performance and applicability of the separation process. In addition, magnetic interactions between naked nanoparticles make them capable of rapid and uncontrolled accumulation under normal synthesis conditions. The most appropriate strategy to stabilize magnetic nanoparticles against oxidation, corrosion and spontaneous accumulation is coating them with organic or mineral materials. ${ }^{8,9}$ Natural organic macromolecules, mostly biopolymers, such as 
chitin, chitosan (CS), cyclodextrin, alginate etc., are used as effective coatings, covering very well these particles..$^{10-12}$

In this research, the $\mathrm{CS} / \mathrm{CoFe}_{2} \mathrm{O}_{4}$ composite was prepared and its structural specifications were characterized. The adsorption properties of the $\mathrm{CS} / \mathrm{CoFe}_{2} \mathrm{O}_{4}$ composite towards the AY17 dye (as a function of $\mathrm{pH}$, temperature, contact time, amount of $\mathrm{CS} / \mathrm{CoFe}_{2} \mathrm{O}_{4}$ and the initial dye concentration) were studied using batch tests. Also, the mechanism of the interaction between AY17 and the prepared composite was discussed. Furthermore, the kinetic parameters, equilibrium isotherms and thermodynamics were determined.

\section{EXPERIMENTAL}

\section{Materials}

Acid Yellow 17 (chemical formula $\mathrm{C}_{16} \mathrm{H}_{10} \mathrm{Cl}_{2} \mathrm{~N}_{4} \mathrm{Na}_{2} \mathrm{O}_{7} \mathrm{~S}_{2}, \mathrm{FW}=551.29 \mathrm{~g} \mathrm{~mol}^{-1}, \lambda_{\max }=$ $402 \mathrm{~nm}$ ) is a reactive anionic azo textile dye that was obtained from Tehranacid Company (Iran). Its chemical structure is illustrated in Figure 1. Low molecular weight chitosan, with the degree of deacetylation of $75-85 \%$, and other common chemicals were all purchased from Sigma-Aldrich, and used without further purification. Double distilled water (DDW) was used to prepare all the solutions.

An appropriate volume of $0.1 \mathrm{M}$ sodium hydroxide and hydrochloric acid solutions was used for carefully adjusting the $\mathrm{pH}$ of the dye solution, which was monitored by a $\mathrm{pH}$ meter.

\section{Preparation of $\mathrm{CS} / \mathrm{CoFe}_{2} \mathrm{O}_{4}$}

In a typical procedure, $2.7 \mathrm{~g} \mathrm{FeCl}_{3} \cdot 6 \mathrm{H}_{2} \mathrm{O}$ and $1.19 \mathrm{~g}$ $\mathrm{CoCl}_{2} \cdot 6 \mathrm{H}_{2} \mathrm{O}$ were dissolved in $40 \mathrm{~mL}$ DDW, followed by intensive sonication for $30 \mathrm{~min}$ to a homogeneous solution, which was denoted as 'solution A'. The chitosan solution was prepared by dissolving $0.8 \mathrm{~g}$ chitosan into $50 \mathrm{~mL}$ acetic acid $(2 \% \mathrm{v} / \mathrm{v})$. To prepare the $\mathrm{CS} / \mathrm{CoFe}_{2} \mathrm{O}_{4}$ composite, the chitosan solution was slowly added to solution $\mathrm{A}$. The temperature of the mixed solution was raised to $80{ }^{\circ} \mathrm{C}$ under simultaneous vigorous stirring. Subsequently, the $\mathrm{pH}$ of the solution was increased to 10.5 , by adding droplets of $2 \mathrm{M}$ $\mathrm{NaOH}$. Afterwards, $0.5 \mathrm{~mL}$ of $25 \mathrm{wt} \%$ glutaraldehyde was added as a cross-linking agent into the mixture. The resulting brownish red suspension was sealed in a Teflon-lined stainless-steel autoclave and maintained at $200{ }^{\circ} \mathrm{C}$ for $4 \mathrm{~h}$ in a furnace. The reaction product $\left(\mathrm{CS} / \mathrm{CoFe}_{2} \mathrm{O}_{4}\right.$ composite) was collected with the help of a magnet, rinsed with DDW and ethanol to remove residual chitosan and inorganic ions, and finally was dried at $60{ }^{\circ} \mathrm{C}$ for $10 \mathrm{~h}$ in a hot air oven. Naked $\mathrm{CoFe}_{2} \mathrm{O}_{4}$ particles were prepared by the same procedure without the addition of chitosan.

\section{Characterization techniques}

Fourier transform infrared (FTIR) spectra (400$4000 \mathrm{~cm}^{-1}$ ) were recorded by a spectrometer (Vector 22, Bruker, USA) by the standard $\mathrm{KBr}$ pellet method. $\mathrm{X}$-ray powder diffraction (XRD) patterns were obtained on an X-ray diffractometer (X'pert PRO, Panalytical) at a voltage of $40 \mathrm{kV}$ and a current of 100 $\mathrm{mA}$, with $\mathrm{CuK} \alpha$ radiation $(\lambda=1.54056 \AA)$. Field emission-electron microscopy (FESEM) images were recorded by using a scanning electron microscope (Sigma, Zeiss), operated at an acceleration voltage of $20.0 \mathrm{kV}$. Energy dispersive X-ray spectra (EDX) were also recorded. Thermogravimetric analysis (TGA) was conducted using a thermal analyzer (STA 1500, Rheometric Scientific, USA), where the samples were heated in the range of $10-800{ }^{\circ} \mathrm{C}$ at the rate of $10{ }^{\circ} \mathrm{C}$ $\min ^{-1}$ under a $\mathrm{N}_{2}$ atmosphere. The assessment of magnetization was performed by a vibrating-sample magnetometer (VSM, Meghnatis Kavir Kashan Co, Iran) at room temperature.<smiles>C=S(C)(=O)c1ccc(N=Nc2c(C)nn(-c3cc(Cl)c(S(C)(=O)=O)cc3Cl)c2C)cc1</smiles>

Figure 1: Chemical structure of Acid Yellow 17 (AY17) dye

\section{Batch adsorption procedure}

A typical batch adsorption experiment was conducted in the following way: $10 \mathrm{mg}$ of $\mathrm{CS} / \mathrm{CoFe}_{2} \mathrm{O}_{4}$ was added into $10 \mathrm{~mL}$ of AY17 solution with an initial dye concentration of $20 \mathrm{mg} \mathrm{L}^{-1}$ in a $25 \mathrm{~mL}$ Erlenmeyer flask, followed by mechanically agitating at $200 \mathrm{rpm}$ for fixed various time. At the end of the adsorption process, the saturated $\mathrm{CS} / \mathrm{CoFe}_{2} \mathrm{O}_{4}$ was separated by a hand-held magnet and the supernatant was immediately subjected to UV-Vis spectroscopy (Lambda 35 UV-Vis spectrophotometer, Perkin Elmer) at $402 \mathrm{~nm}$ to measure the concentration of AY17 in the remaining solution. A standard curve, used to convert absorbance data into concentrations for kinetic and 
thermodynamic studies, was drawn to calculate the dye concentration in each adsorption experiment. The adsorption capacity $\left(q_{E}, \mathrm{mg} \mathrm{g}^{-1}\right.$ ) and the removal percentage $(R(\%))$ were calculated using the following equations:

$$
\begin{aligned}
& q_{t}=\frac{\left(C_{0}-C_{t}\right) V}{M} \\
& \mathrm{R}(\%)=\frac{\left(C_{0}-C_{\tau}\right)}{C_{0}} \times 100
\end{aligned}
$$

where $q\left(\mathrm{mg} \mathrm{g}^{-1}\right)$ is the amount of AY17 adsorbed per unit amount of $\mathrm{CS} / \mathrm{CoFe}_{2} \mathrm{O}_{4}, \mathrm{C}_{0}\left(\mathrm{mg} \mathrm{L}^{-1}\right)$ is the initial concentration of AY17, $M(\mathrm{~g})$ is the mass of the $\mathrm{CS} / \mathrm{CoFe}_{2} \mathrm{O}_{4}, V$ (L) is the volume of AY17 solution, $\mathrm{R}(\%)$ is the removal efficiency of $\mathrm{AY} 17$, and $C_{\mathrm{E}}(\mathrm{mg}$ $\mathrm{L}^{-1}$ ) is the concentration of AY17 at time $t$.

\section{RESULTS AND DISCUSSION Characterization of $\mathrm{CS} / \mathrm{CoFe}_{2} \mathrm{O}_{4}$ FTIR spectra}

Figure 2 ( $a, b$ and $c)$ represents the spectra of pure chitosan, $\mathrm{CS} / \mathrm{CoFe}_{2} \mathrm{O}_{4}$ and naked $\mathrm{CoFe}_{2} \mathrm{O}_{4}$ particles in the range of $400-4000 \mathrm{~cm}^{-1}$, respectively. In Figure 2 (a), the broad and intense peaks near $3436 \mathrm{~cm}^{-1}$ for pure CS correspond to the characteristic absorption bands of the $\mathrm{O}-\mathrm{H}$ bond, which was overlapped with the stretching vibrations of $\mathrm{N}-\mathrm{H}$. The peaks located at 1660 , 1608,1378 and $1085 \mathrm{~cm}^{-1}$ are attributed to the stretching vibrations of the $\mathrm{C}=\mathrm{O}$ group of the $\mathrm{NH}=\mathrm{C}=\mathrm{O}$ bond, the rocking vibrations of the $\mathrm{N}-$ $\mathrm{H}$ bond, stretching of $\mathrm{C}-\mathrm{OH}$, and stretching of $\mathrm{C}-$ $\mathrm{O}-\mathrm{C}$, respectively. The peak at $2881 \mathrm{~cm}^{-1}$ is ascribed to symmetric stretching vibrations in the $\mathrm{CH}_{2}$ bond of chitosan. ${ }^{13}$

The FTIR spectrum of $\mathrm{CS} / \mathrm{CoFe}_{2} \mathrm{O}_{4}$ shows two absorption bands at 3420 and $1624 \mathrm{~cm}^{-1}$, which belong to the stretching vibrations of $\mathrm{N}-\mathrm{H}$ of amine (and $\mathrm{O}-\mathrm{H}$ ) and scissoring vibrations of $\mathrm{N}-\mathrm{H}$ of primary amine, respectively, appeared in the chitosan spectrum because of the free amine groups available in cross-linked chitosan. In addition, the typical peaks observed at around 418 and $580 \mathrm{~cm}^{-1}$ in the IR spectrum of $\mathrm{CS} / \mathrm{CoFe}_{2} \mathrm{O}_{4}$ and naked $\mathrm{CoFe}_{2} \mathrm{O}_{4}$ particles (Fig. 2 (b) and (c)) correspond to the stretching vibrations of $\mathrm{Co}-\mathrm{O}$ and $\mathrm{Fe}-\mathrm{O}$ bonds in the ferrite lattice. After chitosan coating was applied on the surface of $\mathrm{CoFe}_{2} \mathrm{O}_{4}$, the vibrations of $\mathrm{Fe}-\mathrm{O}$ become weaker in $\mathrm{CS} / \mathrm{CoFe}_{2} \mathrm{O}_{4}{ }^{14}$
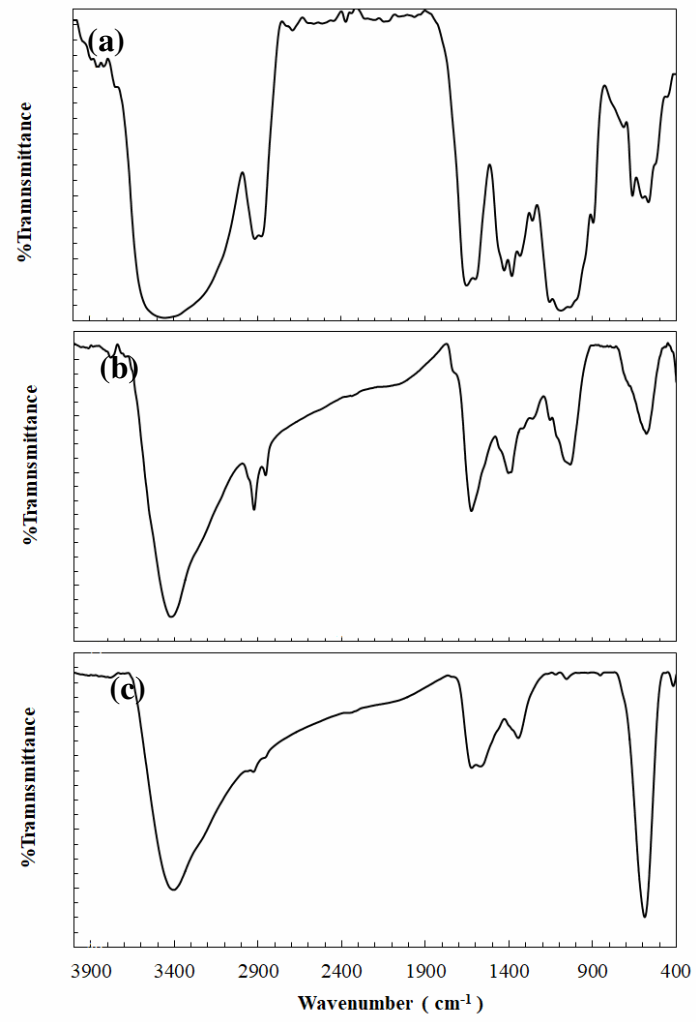

Figure 2: FTIR spectra of (a) CS, (b) $\mathrm{CS} / \mathrm{CoFe}_{2} \mathrm{O}_{4}$, and (c) naked $\mathrm{CoFe}_{2} \mathrm{O}_{4}$ 


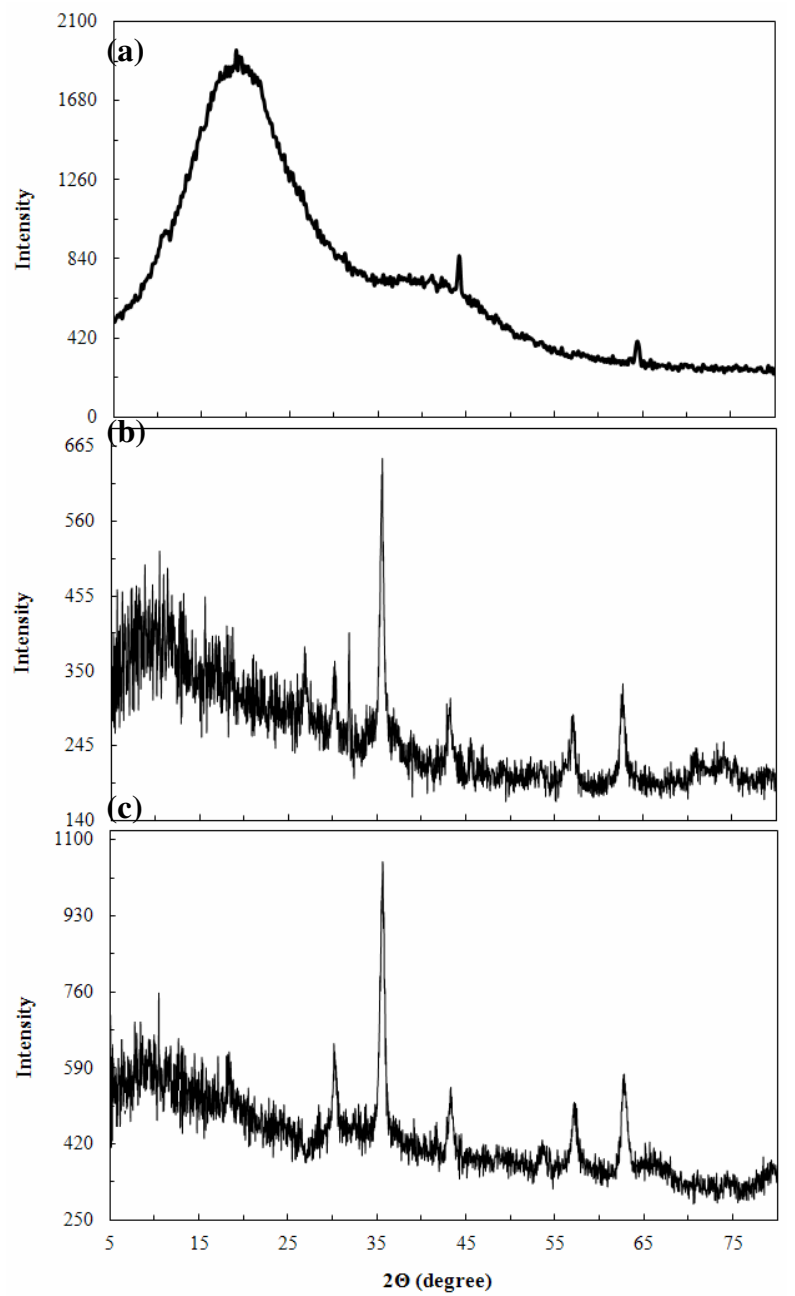

Figure 3: XRD patterns of (a) CS, (b) $\mathrm{CS} / \mathrm{CoFe}_{2} \mathrm{O}_{4}$, and (c) naked $\mathrm{CoFe}_{2} \mathrm{O}_{4}$

\section{XRD patterns}

XRD patterns of pure chitosan, $\mathrm{CS} / \mathrm{CoFe}_{2} \mathrm{O}_{4}$ and naked $\mathrm{CoFe}_{2} \mathrm{O}_{4}$ are shown in Figure 3 (a), (b) and (c), respectively. The broad peak appearing in Figure 3 (a) and (b), at the $2 \theta$ value of $20.5^{\circ}$, is due to the presence of chitosan with the amorphous state. ${ }^{15}$ Seven main characteristic peaks, at $2 \theta$ of $18.3^{\circ}, 30.2^{\circ}, 35.5^{\circ}, 43.2^{\circ}, 45.5^{\circ}$, $57.0^{\circ}$ and $62.6^{\circ}$, visible in Figure $3(\mathrm{~b})$ and (c), belong to (111), (220), (311), (400), (422), (511) and (440) crystalline plates of cobalt ferrite with a cubic spinel structure, according to JCPDS card No. 22-1086, ${ }^{16,17}$ which are observed in both naked $\mathrm{CoFe}_{2} \mathrm{O}_{4}$ and $\mathrm{CoFe}_{2} \mathrm{O}_{4} / \mathrm{CS}$. The sharp and strong peaks confirm that the two products were successfully prepared and well crystallized. ${ }^{13}$

\section{Morphology}

The morphology and the particle size distribution of the $\mathrm{CS} / \mathrm{CoFe}_{2} \mathrm{O}_{4}$ were further analyzed by FE-SEM. ${ }^{18}$ From the FE-SEM image depicted in Figure 4, the spherical shape of $\mathrm{CoFe}_{2} \mathrm{O}_{4}$ particles is clearly observed, with the estimated cluster size ranging between $30-80 \mathrm{~nm}$. They are agglomerated to some extent on the relatively rough surface of chitosan.

\section{EDX analysis}

The EDX spectrum of $\mathrm{CS} / \mathrm{CoFe}_{2} \mathrm{O}_{4}$ and the quantitative elemental composition shown in Figure 5 demonstrate the presence of $\mathrm{C}, \mathrm{O}, \mathrm{N}, \mathrm{Fe}$ and $\mathrm{Co}$ elements in $\mathrm{CS} / \mathrm{CoFe}_{2} \mathrm{O}_{4}$. The carbon and nitrogen signals originate from chitosan, while the 
$\mathrm{Co}$ and $\mathrm{Fe}$ signals, with the atomic ratio of $1: 2$, come from the $\mathrm{CoFe}_{2} \mathrm{O}_{4}$ particles, which is evidence of $\mathrm{CoFe}_{2} \mathrm{O}_{4}$ in the composite.

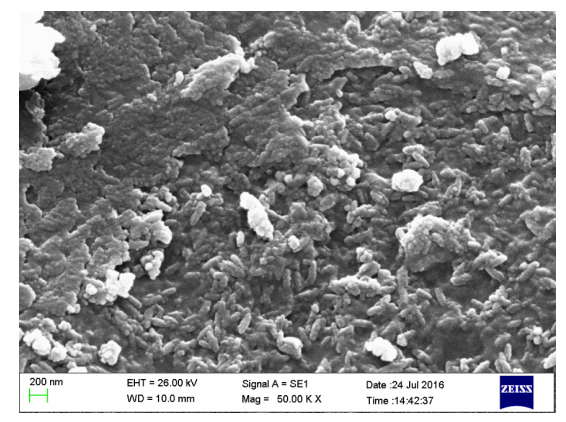

Figure 4: FE-SEM image of $\mathrm{CS} / \mathrm{CoFe}_{2} \mathrm{O}_{4}$

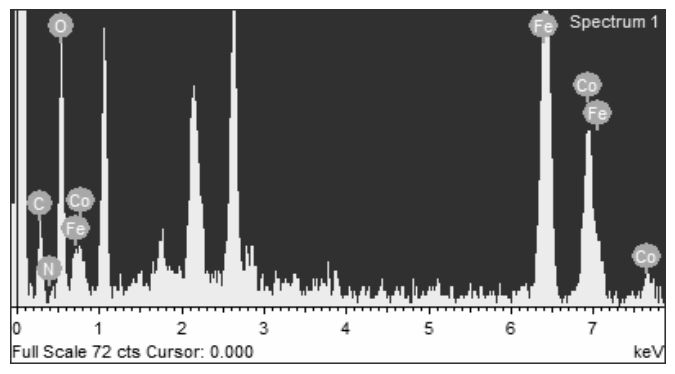

\begin{tabular}{ccc}
\hline Element & Weight $\%$ & Atomic\% \\
\hline C K & 19.26 & 31.99 \\
N K & 6.56 & 9.34 \\
O K & 36.44 & 45.44 \\
Fe K & 24.32 & 8.69 \\
Co K & 13.42 & 4.54 \\
\hline
\end{tabular}

Figure 5: EDX pattern of $\mathrm{CS} / \mathrm{CoFe}_{2} \mathrm{O}_{4}$ and its quantitative elemental composition

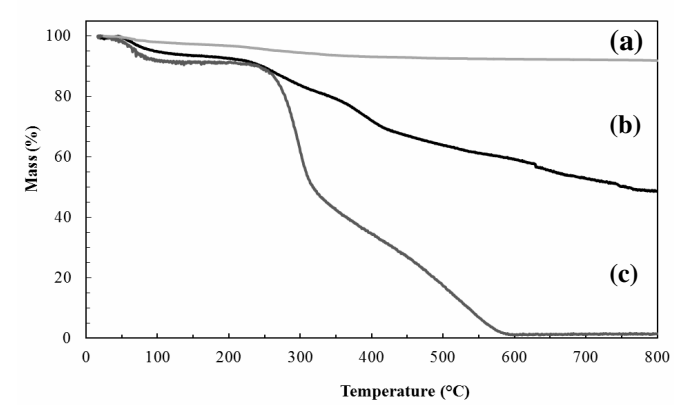

Figure 6: TGA thermograms of (a) naked $\mathrm{CoFe}_{2} \mathrm{O}_{4}$, (b) $\mathrm{CS} / \mathrm{CoFe}_{2} \mathrm{O}_{4}$, and (c) $\mathrm{CS}$

\section{TGA analysis}

The TGA results for naked $\mathrm{CoFe}_{2} \mathrm{O}_{4}$, $\mathrm{CS} / \mathrm{CoFe}_{2} \mathrm{O}_{4}$ composite and pure $\mathrm{CS}$, under nitrogen, are shown in Figure 7 (a), (b) and (c), respectively. The curve of naked $\mathrm{CoFe}_{2} \mathrm{O}_{4}$ in Figure 6 (a) exhibits no remarkable peaks. The initial mass loss of $\mathrm{CoFe}_{2} \mathrm{O}_{4}$ below $200{ }^{\circ} \mathrm{C}$ is of about $3.1 \%$, which is attributed to the loss of physically adsorbed moisture. The mass loss of $5.2 \%$ occurring from 200 to $800{ }^{\circ} \mathrm{C}$ can be

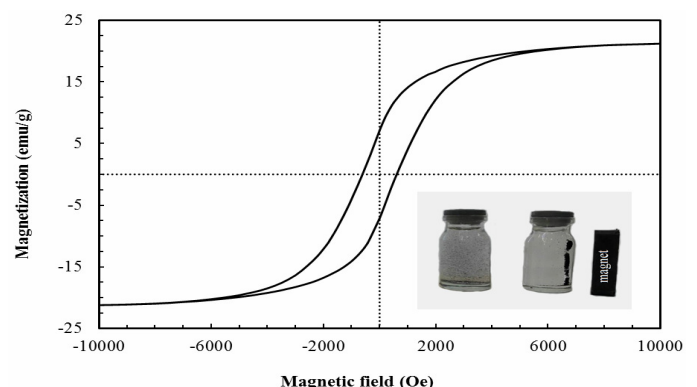

Figure 7: Magnetic hysteresis curve for $\mathrm{CS} / \mathrm{CoFe}_{2} \mathrm{O}_{4}$. Inset displays a photograph of $\mathrm{CS} / \mathrm{CoFe}_{2} \mathrm{O}_{4}$ dispersion in solution and magnetic separation from solution

ascribed to the loss of residual solvents used in the synthesis process. ${ }^{19}$ For $\mathrm{CS} / \mathrm{CoFe}_{2} \mathrm{O}_{4}$ in Figure 6 (b), the mass loss is around $9 \%$ below $200{ }^{\circ} \mathrm{C}$, similarly owing to the removal of adsorbed water molecules through physical and chemical interactions, but the considerable degradation observed between $200{ }^{\circ} \mathrm{C}$ and $570{ }^{\circ} \mathrm{C}$ corresponds to the breakdown of the main CS chains coating the magnetic particles. Beyond $570{ }^{\circ} \mathrm{C}$, no significant change is observed in the mass, 
indicating the presence of ferrite cobalt above this temperature. For CS in Figure 6 (c), nearly 9\% loss of CS mass is observed at temperatures lower than $200{ }^{\circ} \mathrm{C}$, resulting from evaporation of adsorbed moisture. The decomposition of acetylated and deacetylated units of CS occurring at $250-450{ }^{\circ} \mathrm{C}$ causes the main mass loss of CS. ${ }^{15,20}$ According to the TGA curves, the CS content of the $\mathrm{CS} / \mathrm{CoFe}_{2} \mathrm{O}_{4}$ composite is estimated to be about $40 \%$. The introduction of $\mathrm{CoFe}_{2} \mathrm{O}_{4}$ particles into the CS polymer decreases its crystallinity. The results of TGA further confirmed that the $\mathrm{CoFe}_{2} \mathrm{O}_{4}$ particles were successfully coated with the CS polymer, supporting the findings of the FTIR and EDX analyses.

\section{Magnetic property}

The magnetic behavior of $\mathrm{CS} / \mathrm{CoFe}_{2} \mathrm{O}_{4}$ was analyzed at room temperature with applied magnetic field sweeping from -10 to $+10 \mathrm{kOe}$ and the result is shown in Figure 7. It was observed that an increase in the external magnetic field reinforces magnetization of $\mathrm{CS} / \mathrm{CoFe}_{2} \mathrm{O}_{4}$ and its saturation magnetization value $\left(M_{\mathrm{s}}\right)$ reaches 21.21 emu $\mathrm{g}^{-1}$. Comparatively, this is lower than that reported for bare $\mathrm{CoFe}_{2} \mathrm{O}_{4}\left(49.55 \mathrm{emu} \mathrm{g}^{-1}\right){ }^{18}$ The decreased saturation magnetization was most likely attributed to the presence of the nonmagnetic chitosan coating on the surface of $\mathrm{CoFe}_{2} \mathrm{O}_{4}$ particles. $^{21}$ The insert of Figure 7 indicates that $\mathrm{CS} / \mathrm{CoFe}_{2} \mathrm{O}_{4}$ can be conveniently attracted and separated from an aqueous solution by a hand-held magnet beside the vial.

\section{pH at point of zero charge}

The $\mathrm{pH}_{\mathrm{pzc}}(\mathrm{pH}$ at the point of zero charge, i.e. the $\mathrm{pH}$ at which the electric charge density of the adsorbent surface is zero) is a critical parameter for explaining the efficacy of the adsorption process concerning the electrostatic interactions between adsorbent and adsorbate materials. ${ }^{15}$ The $\mathrm{pH}_{\mathrm{pzc}}$ of $\mathrm{CS} / \mathrm{CoFe}_{2} \mathrm{O}_{4}$ was measured by mixing $0.02 \mathrm{~g}$ of $\mathrm{CS} / \mathrm{CoFe}_{2} \mathrm{O}_{4}$ and $25 \mathrm{~mL}$ of $0.1 \mathrm{~mol}^{-1}$ sodium chloride electrolyte solution in the initial $\mathrm{pH}$ range of 2.5-9.0 at $298 \mathrm{~K}$, with continuous stirring at $200 \mathrm{rpm}$ for $24 \mathrm{~h}$. Figure 8 shows the curve of $\Delta \mathrm{pH}\left[\mathrm{pH}_{\text {intial }}-\mathrm{pH}_{\text {funal }}\right]$ versus $\mathrm{pH}_{\text {initial. }}$. The $\mathrm{pH}_{\mathrm{pzc}}$ was estimated to be 6.8 .

\section{Adsorption studies}

\section{Effect of initial solution $\mathrm{pH}$}

The $\mathrm{pH}$ may be one of the key factors controlling the adsorption of pollutants onto adsorbents. ${ }^{22}$ As seen in Figure 9 (a), the adsorption process was strongly dependent on $\mathrm{pH}$. The highest dye removal efficiency (83\%) was found to be at the initial $\mathrm{pH}$ 4.0. This phenomenon can be attributed to the enhanced electrostatic attractions between the negatively charged AY17 dye anions and the positively charged surface of $\mathrm{CS} / \mathrm{CoFe}_{2} \mathrm{O}_{4}$ at lower $\mathrm{pH}$ values. Two sulfonate groups $\left(-\mathrm{SO}_{3}^{-}\right)$of AY17 (shown in Fig. 1) are readily dissociated and have negative charges in aqueous solution. The amine groups $\left(-\mathrm{NH}_{2}\right)$ of chitosan molecules on the surface of $\mathrm{CS} / \mathrm{CoFe}_{2} \mathrm{O}_{4}$ can be protonated as a form of $-\mathrm{NH}_{3}^{*}$. Therefore, the adsorption mechanism of the acidic dye $\left(\right.$ Dye- $\left.-\mathrm{SO}_{3}^{-} \mathrm{Na}^{+}\right)$is presented in the following equation: ${ }^{23}$

$$
\begin{aligned}
& \mathrm{R}-\mathrm{NH}^{+}+\mathrm{H}^{+} \rightleftharpoons \mathrm{R}-\mathrm{NH}_{3}^{+} \\
& \text {Dye }-\mathrm{SO}_{3}^{-} \mathrm{Na}^{+} \stackrel{\mathrm{H}_{2} \mathrm{O}}{\longrightarrow} \mathrm{Dye}-\mathrm{SO}_{3}^{-}+\mathrm{Na}^{+} \\
& \mathrm{R}-\mathrm{NH}_{3}^{+}+\mathrm{Dye}-\mathrm{SO}_{3}^{-} \mathrm{Na}^{+} \rightleftharpoons \mathrm{R}-\mathrm{NH}_{3}^{+}-\mathrm{O}_{3} \mathrm{~S}-\mathrm{Dye}
\end{aligned}
$$

where $\mathrm{R}$ is the alkyl group of the original form of chitosan in the $\mathrm{CS} / \mathrm{CoFe}_{2} \mathrm{O}_{4}$.

In extremely acidic $\mathrm{pH}$ ranges (less than the optimum $\mathrm{pH}$ value of 4.0), dye dissociation decreases, leading to a lower concentration of the anionic dye species available to interact with the positively charged sites of $\mathrm{CS} / \mathrm{CoFe}_{2} \mathrm{O}_{4}$.

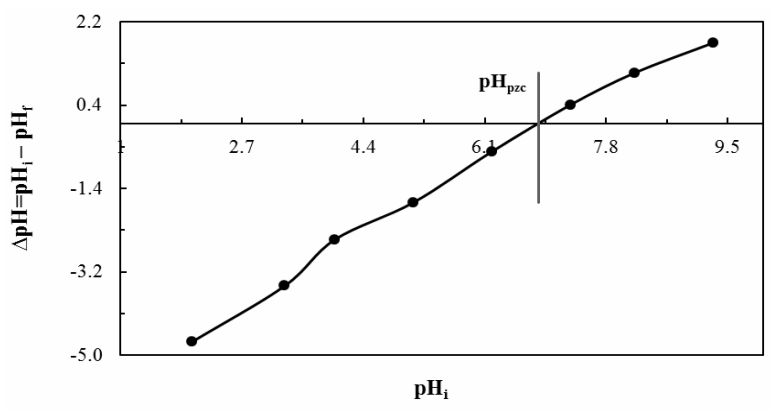

Figure 8: $\mathrm{pH}$ point of zero charge of $\mathrm{CS} / \mathrm{CoFe}_{2} \mathrm{O}_{4}$ 

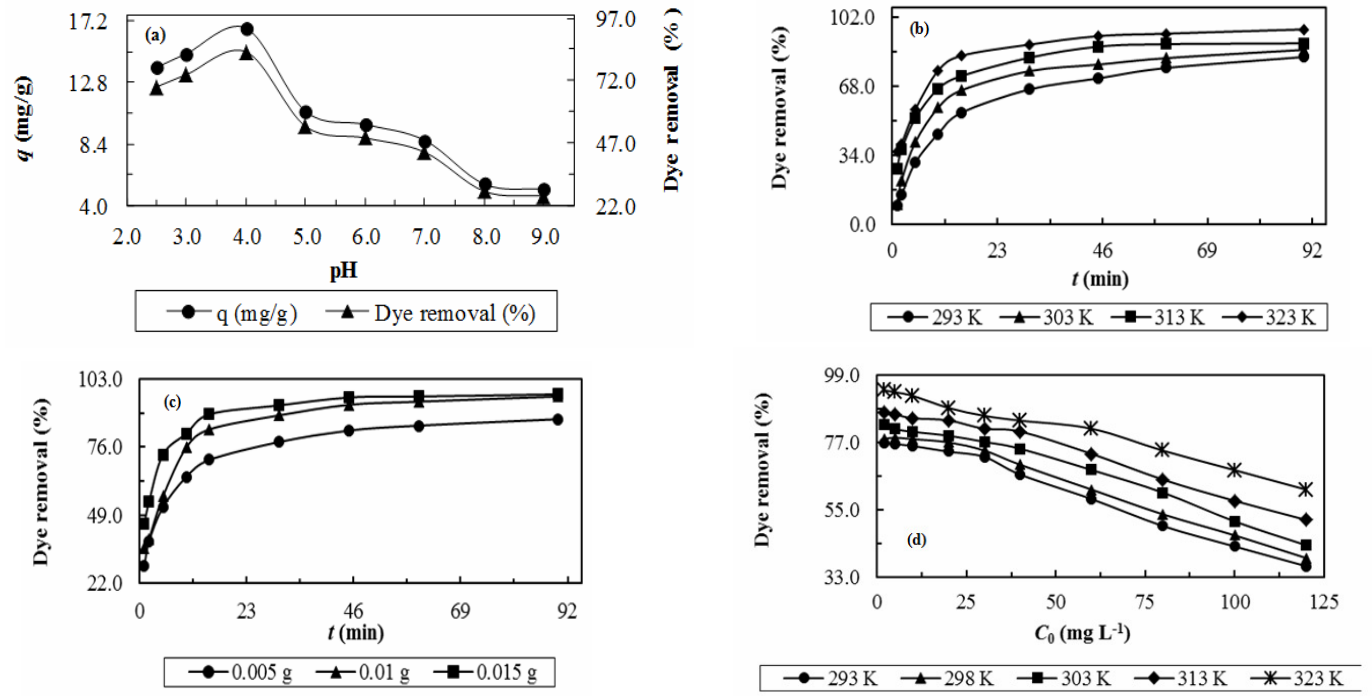

Figure 9: Parameters affecting AY17 removal efficiency: (a) initial solution $\mathrm{pH}$, (b) temperature and contact time, (c) $\mathrm{CS} / \mathrm{CoFe}_{2} \mathrm{O}_{4}$ adsorbent dosage and contact time, and (d) initial AY17 dye concentration

Therefore, the dye removal efficiency reduced at $\mathrm{pH}<4.0$. The point of zero charge for $\mathrm{CS} / \mathrm{CoFe}_{2} \mathrm{O}_{4}$ was found to be 6.8. Therefore, the surface charge of the $\mathrm{CS} / \mathrm{CoFe}_{2} \mathrm{O}_{4}$ is positive at $\mathrm{pH}<6.8$, which is favorable for the adsorption of an anionic dye.

However, at a $\mathrm{pH}$ above 6.8 , the $\mathrm{CS} / \mathrm{CoFe}_{2} \mathrm{O}_{4}$ has negative surface potential, which increases repulsion between its surface and AY17. Additionally, more $\mathrm{OH}^{-}$ions are available to compete with the anionic sulfonate groups in alkaline medium, thereby AY17 removal efficiency decreases significantly. ${ }^{24}$ In summary, the optimum $\mathrm{pH}$ value for AY17 adsorption was determined to be 4.0. All subsequent adsorption experiments were conducted at the optimum $\mathrm{pH}$ value. The inset of Figure 9 (a) shows a photographic image of AY17 solution before (left) and after (right) adsorption onto $0.01 \mathrm{~g}$ $\mathrm{CS} / \mathrm{CoFe}_{2} \mathrm{O}_{4}$ at $\mathrm{pH} 4.0$ and $323 \mathrm{~K}$. Obviously, the color of the solution disappeared after treatment with the adsorbent.

\section{Effect of temperature and contact time}

The contact time between adsorbent and adsorbate is another significant parameter for evaluating the adsorption properties of adsorbents. Figure 9 (b) illustrates the impact of contact time on AY17 removal efficiency (\%) at various temperatures. The trend of the curves is similar to those described in other studies reported in the literature. Initially, the removal efficiency increased sharply. After a while, it rose mildly with further increase of contact time and steadily at equilibrium time. The rapid adsorption at first may be due to the abundant availability of active sites on $\mathrm{CS} / \mathrm{CoFe}_{2} \mathrm{O}_{4}$ and the $\mathrm{AY} 17$ anion dyes interact easily with the adsorption sites, while the following slower rate can be explained by the exhaustion of the open adsorptive sites and by the repulsion between the dye anions and the bulk phases, which hindered the binding of AY17 to the remaining active sites. ${ }^{15}$

AY17 removal efficiency in $45 \mathrm{~min}$ at temperatures of 293, 303, 313 and $323 \mathrm{~K}$ was $72 \%, 78 \%, 87 \%$ and $92 \%$, respectively (Fig. 9 (b)). Obviously, an increase in the temperature led to an enhancement in dye removal efficiency. Therefore, AY17 adsorption onto $\mathrm{CS} / \mathrm{CoFe}_{2} \mathrm{O}_{4}$ was endothermic. Moreover, with increasing the temperature, the adsorption process reached equilibrium more quickly. It seems that not only the number of adsorptive sites augments at a higher temperature, but also the penetration of dye anions into the possible surface cavities is facilitated. ${ }^{25}$

\section{Effect of $\mathrm{CS} / \mathrm{CoFe}_{2} \mathrm{O}_{4}$ dosage and contact time}

The dye removal efficiency is significantly influenced by the amount, size and pore volume of the adsorbent, showing its cost-effectiveness in the adsorption processes. ${ }^{26}$ The plot of AY17 
removal efficiency (\%) versus time ( $\mathrm{min}$ ) at various $\mathrm{CS} / \mathrm{CoFe}_{2} \mathrm{O}_{4}$ doses $(\mathrm{g})$ is shown in Figure 9 (c). It was found that removal efficiency increased with an increasing initial amount of $\mathrm{CS} / \mathrm{CoFe}_{2} \mathrm{O}_{4}$. It can be ascribed to the increase in the surface area of the adsorbent, as well as the abundant accessibility of adsorptive sites in spite of the fixed finite number of dye anions. ${ }^{27}$ The smooth enhancement in the AY17 removal efficiency at a higher adsorbent amount can be due to decreasing the unit contact area between AY17 and $\mathrm{CS} / \mathrm{CoFe}_{2} \mathrm{O}_{4}$, as well as the diffusion path length resulting from overlapping or aggregation of the adsorptive sites. The removal efficiency in $60 \mathrm{~min}$ was found to be $84 \%, 94 \%$ and $96 \%$ for $0.005,0.01$ and $0.015 \mathrm{~g}$ of $\mathrm{CS} / \mathrm{CoFe}_{2} \mathrm{O}_{4}$, respectively. However, a dose of $0.01 \mathrm{~g}$ was used for subsequent experiments.

\section{Effect of initial AY17 dye concentration}

The initial dye concentration plays a predominant role in color removal. Figure 9 (d) illustrates the effect of initial AY17 concentration on color removal by $\mathrm{CS} / \mathrm{CoFe}_{2} \mathrm{O}_{4}$ at several temperatures. As seen from Figure 9 (d), AY17 removal efficiency fell from $78 \%$ to $36 \%$ as the initial AY17 concentration increased from 2 to $120 \mathrm{mg} \mathrm{L}^{-1}$ at $293 \mathrm{~K}$. The reduction of dye removal efficiency may be due to the fact that at the higher initial dye concentration, the total exiting adsorptive sites are confined as a result of the fixed amount of adsorbent. Hence, saturation of the adsorptive sites of the adsorbent with dye anions may occur as the adsorption process continues, ${ }^{28}$ leading to a decrease in dye removal with an increase in dye concentration. Furthermore, from Figure 9 (d), it is observed that the removal efficiency improved from $36 \%$ at 293 $\mathrm{K}$ to $61 \%$ at $323 \mathrm{~K}$ at an initial concentration of $120 \mathrm{mg} \mathrm{L}^{-1}$.

\section{Adsorption kinetics}

The study of adsorption kinetics is necessary for wastewater treatment using adsorbents since it provides highly valuable information on reaction pathways and the mechanisms controlling the adsorption process, such as chemical reaction, mass transfer and diffusion, ${ }^{29}$ which is helpful in designing an effective and fast model for the adsorption of colored pollutants. Hence, five common kinetic models were employed to fit the kinetic adsorption data of AY17 dye onto $\mathrm{CS} / \mathrm{CoFe}_{2} \mathrm{O}_{4}$ by the non-linear method using Mathematica 9.0 software, that is, the Lagergren pseudo-first order, ${ }^{30}$ pseudo-second order, ${ }^{31}$ intraparticle diffusion, ${ }^{32}$ simplified Elovich, ${ }^{33}$ and fractional power ${ }^{34}$ models. The mathematical equations for these models are given in Table 1, where $q_{e}\left(\mathrm{mg} \mathrm{g}^{-1}\right)$ and $q_{t}\left(\mathrm{mg} \mathrm{g}^{-1}\right)$ are the adsorption capacity at equilibrium and any time $t$, respectively; $k_{1}\left(\mathrm{~min}^{-1}\right)$ and $k_{2}\left(\mathrm{~g} \mathrm{mg}^{-1} \mathrm{~min}^{-1}\right)$ are the pseudo-first order and pseudo-second order constant, respectively; $k_{1}\left(\mathrm{mg} \mathrm{g}^{-1} \mathrm{~min}^{-1 / 2}\right)$ is the intraparticle diffusion rate constant; $C\left(\mathrm{mg} \mathrm{g}^{-1}\right)$ is a constant related to boundary layer thickness; $\alpha\left(\mathrm{mgg}^{-1} \mathrm{~min}^{-1}\right)$ is the initial adsorption rate constant; $\beta\left(\mathrm{g} \mathrm{mg}^{-1}\right)$ is the desorption constant; $a\left(\mathrm{mgg}^{-1} \mathrm{~min}^{-b}\right)$ is the fractional power rate constant; $b$ is the power of the fractional power model. The parameters of the kinetic models, along with the correlation coefficients $\left(R^{2}\right)$ resulted by fitting the models to experimental data at temperatures of 293, 303, 313 and $323 \mathrm{~K}$ were summarized in Table 1. The non-linear plots of the kinetics models of AY17 adsorption are shown in Figure 10.

As can be seen from Table 1, the correlation coefficients obtained from the pseudo-second order model are above 0.997 , higher than those of the other models. In addition, compared with the pseudo-first order model, the values of $q_{e}$ calculated using the pseudo-second order model are more consistent with the experimental values of $q_{e}$, given in the last row of Table 1, for all the temperatures studied. Based on these results, the pseudo-second order model described better the kinetic adsorption behavior of AY17 onto the $\mathrm{CS} / \mathrm{CoFe}_{2} \mathrm{O}_{4}$ magnetic composite. As seen in Table 1, the values of the pseudo-second order constant, $k_{2}$, decreased from $0.0056 \mathrm{~g} \mathrm{mg}^{-1} \mathrm{~min}^{-1}$ to $0.0189 \mathrm{~g} \mathrm{mg}^{-1} \mathrm{~min}^{-1}$ with the increase in temperature from $293 \mathrm{~K}$ to $323 \mathrm{~K}$. Meanwhile, the calculated $q_{\mathrm{e}}$ improved from $17.97 \mathrm{mg} \mathrm{g}^{-1}$ at 293 $\mathrm{K}$ to $19.47 \mathrm{mg} \mathrm{g}^{-1}$ at $323 \mathrm{~K}$. In fact, with the rise in temperature, the diffusion of AY17 anions into the pores of the $\mathrm{CS} / \mathrm{CoFe}_{2} \mathrm{O}_{4}$ adsorbent was facilitated. Besides, more AY17 anions gained sufficient kinetic energy for interaction with the adsorptive active sites of $\mathrm{CS} / \mathrm{CoFe}_{2} \mathrm{O}_{4}$, resulting in an enhancement of the adsorption rate.

\section{Activation energy of adsorption}

The activation energy of AY17 adsorption onto $\mathrm{CS} / \mathrm{CoFe}_{2} \mathrm{O}_{4}$ was calculated from the rate constants $\left(k_{2}\right)$ obtained for the experiments conducted in the range of 293-323 K. 
Table 1

Non-linear kinetic parameters for AY17 adsorption onto CS/CoFe $\mathrm{O}_{4}$ at various temperatures

\begin{tabular}{|c|c|c|c|c|c|}
\hline \multirow{2}{*}{ Kinetic models } & \multirow{2}{*}{ Parameters } & \multicolumn{4}{|c|}{ Temperature (K) } \\
\hline & & 293 & 303 & 313 & 323 \\
\hline Pseudo-first order & $k_{1}\left(\min ^{-1}\right)$ & 0.0872 & 0.1277 & 0.2140 & 0.2465 \\
\hline \multirow{2}{*}{$q_{\mathrm{e}}=q_{e}\left(1-\mathrm{e}^{-k_{1} \mathrm{e}}\right)$} & $q_{e c g l}\left(\mathrm{mgg}^{-1}\right)$ & 15.3428 & 16.1513 & 16.8312 & 18.0335 \\
\hline & $\mathrm{R}^{2}$ & 0.9968 & 0.9981 & 0.9918 & 0.9913 \\
\hline \multirow{2}{*}{$\begin{array}{l}\text { Pseudo-second order } \\
\qquad k_{2} q_{e}^{2} t\end{array}$} & $k_{2}\left(\mathrm{~g} \mathrm{mg}^{-1} \mathrm{~min}^{-1}\right)$ & 0.0056 & 0.0087 & 0.0169 & 0.0189 \\
\hline & $q_{\text {qeal }}\left(\mathrm{mg} \mathrm{g}^{-1}\right)$ & 17.9709 & 18.266 & 18.3228 & 19.4722 \\
\hline$q_{t}=\overline{1+k_{2} q_{e} t}$ & $\mathrm{R}^{2}$ & 0.9997 & 0.9995 & 0.9985 & 0.9973 \\
\hline Intraparticle diffusion & $k_{\mathrm{i}}\left(\mathrm{mg} \mathrm{g}^{-1} \mathrm{~min}^{-1 / 2}\right)$ & 1.7476 & 1.7018 & 1.4330 & 1.4279 \\
\hline \multirow{2}{*}{$q_{i}=k_{i} t^{0.5}+C$} & $C\left(\mathrm{mgg}^{-1}\right)$ & 2.0589 & 3.7172 & 6.8762 & 8.1967 \\
\hline & $\mathrm{R}^{2}$ & 0.9821 & 0.9707 & 0.9833 & 0.9833 \\
\hline \multirow{5}{*}{$\begin{array}{l}\text { Simplified Elovich } \\
q_{\varepsilon}=\frac{1}{\beta} \ln (\alpha \beta)+\frac{1}{\beta} \ln t \\
\text { Fractional power }\end{array}$} & $\alpha\left(\mathrm{mgg}^{-1} \min ^{-1}\right)$ & 4.8117 & 7.0525 & 21.0018 & 32.2607 \\
\hline & $\beta\left(\mathrm{gmg}^{-1}\right)$ & 0.2885 & 0.2840 & 0.3372 & 0.3365 \\
\hline & $\mathrm{R}^{2}$ & 0.9984 & 0.9966 & 0.9979 & 0.9965 \\
\hline & $a\left(\mathrm{mgg}^{-1} \mathrm{~min}^{-b}\right)$ & 3.5569 & 4.8840 & 7.2483 & 8.4204 \\
\hline & $b$ & 0.3593 & 0.3019 & 0.2217 & 0.2022 \\
\hline \multirow[t]{2}{*}{$q_{t}=a t^{b}$} & $\mathrm{R}^{2}$ & 0.9892 & 0.9826 & 0.99209 & 0.9924 \\
\hline & $q_{\text {expp }}\left(\mathrm{mg} \mathrm{g}^{-1}\right)$ & 16.4948 & 17.1915 & 17.8423 & 19.2132 \\
\hline
\end{tabular}

*Experimental conditions: $\mathrm{pH} 4.0,0.01 \mathrm{~g}$ of $\mathrm{CS} / \mathrm{CoFe}_{2} \mathrm{O}_{4}, 10 \mathrm{~mL}$ of $20.0 \mathrm{mg} \mathrm{L}^{-1}$ of $\mathrm{AY} 17$ solution
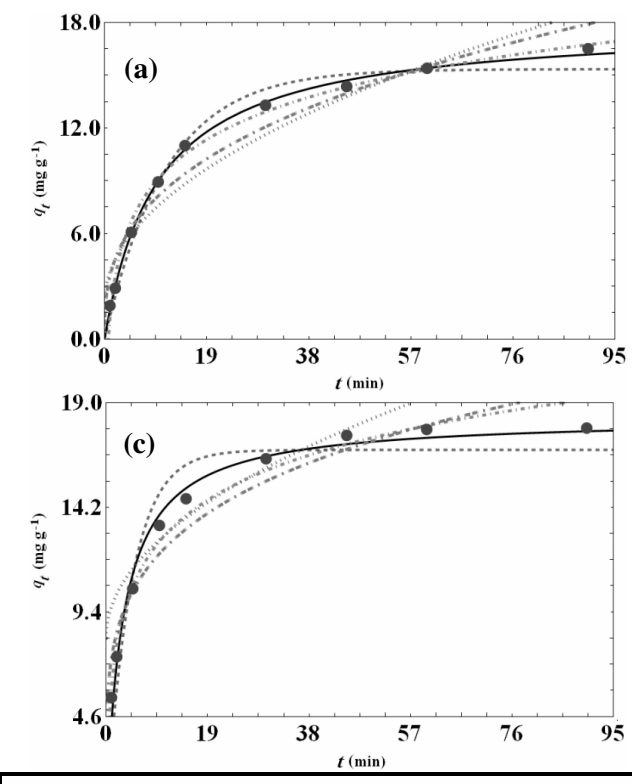
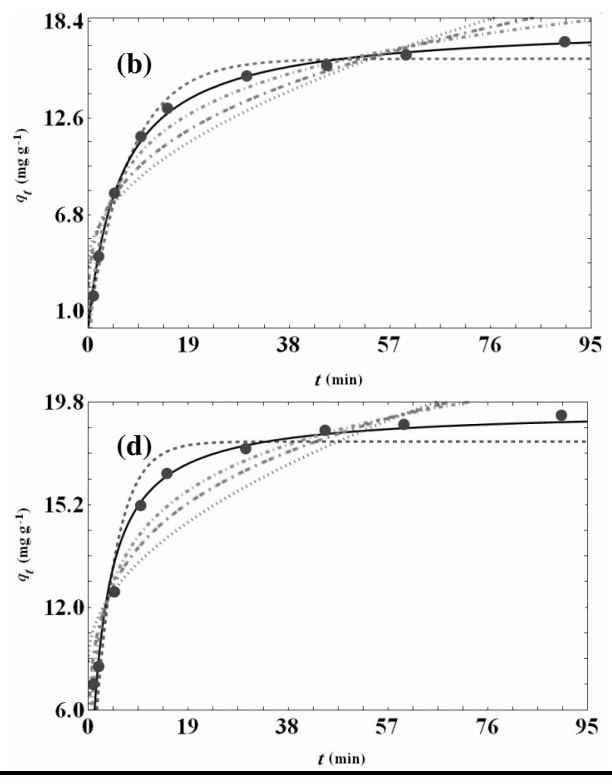

Figure 10: Non-linear plots of kinetic models for the adsorption of AY17 onto CS/CoFe $\mathrm{O}_{4}$ at temperatures of (a) 293, (b) 303 , (c) 313 , (d) $323 \mathrm{~K}$ (black circles show experimental data; experimental conditions: $\mathrm{pH} 4.0$, $0.01 \mathrm{~g}$ of $\mathrm{CS} / \mathrm{CoFe}_{2} \mathrm{O}_{4}, 10 \mathrm{~mL}$ of $20.0 \mathrm{mg} \mathrm{L}{ }^{-1}$ of $\mathrm{AY} 17$ solution)

The Arrhenius equation was used for this purpose:

$k_{2}=A \mathrm{e}^{-\frac{\dot{E}_{\bar{R}}}{R T}}$

where $k_{2}\left(\mathrm{~g} \mathrm{mg}^{-1} \mathrm{~min}^{-1}\right)$ is the rate constant for the pseudo-second-order kinetic model; $A\left(\mathrm{~g} \mathrm{mg}^{-1} \mathrm{~min}^{-1}\right)$ is the temperature-independent Arrhenius factor; $E_{a}\left(\mathrm{~J} \mathrm{~mol}^{-1}\right)$ is the activation energy, $\mathbb{R}\left(8.314 \mathrm{~J} \mathrm{~mol}^{-1} \mathrm{~K}^{-1}\right)$ is the universal gas constant, and $T(K)$ is temperature.

The magnitude of activation energy may provide evidence about the physical or chemical nature of the adsorption process. The physical adsorption normally has a low activation energy (5-50 $\left.\mathrm{kJ} \mathrm{mol}^{-1}\right)$, while chemical adsorption has a 
high activation energy $\left(60-800 \mathrm{~kJ} \mathrm{~mol}^{-1}\right) .^{35}$ The obtained value of $\bar{E}_{a}, 29.66 \mathrm{~kJ} \mathrm{~mol}{ }^{-1}$, for the adsorption of AY17 onto $\mathrm{CS} / \mathrm{CoFe}_{2} \mathrm{O}_{4}$ was within the range of physisorption.

\section{Adsorption isotherms}

Adsorption isotherms can describe surface properties and the affinity of an adsorbent, which are effective factors on the interactive behavior between adsorbent and adsorbate materials, aiding the design of a desired adsorption system. Five well-known adsorption isotherms, namely Langmuir, ${ }^{36} \quad$ Freundlich, ${ }^{37}$ DubininRadushkevich, ${ }^{38}$ Temkin $^{39}$ and Jovanovic, ${ }^{40}$ were employed here to fit with the adsorption isotherm data of AY17 onto $\mathrm{CS} / \mathrm{CoFe}_{2} \mathrm{O}_{4}$ and naked $\mathrm{CoFe}_{2} \mathrm{O}_{4}$, using the non-linear method. The equation of the tested models are given in Table 2 , where $q_{m}\left(\mathrm{mgg}^{-1}\right)$ is the maximum adsorption capacity of the adsorbent to generate a single layer; $K_{L}\left(\mathrm{~L} \mathrm{mg}^{-1}\right)$ is the Langmuir isotherm constant associated with free energy and the affinity of adsorption, $K_{F}\left(\mathrm{mg}^{1-\frac{1}{n}} \mathrm{~L}^{\frac{1}{n}} \mathrm{~g}^{-1}\right)$ and $n$ are Freundlich isotherm constants, indicating the adsorption capacity; $n$ is the heterogeneity factor, related to adsorption capacity; $q_{s}\left(\mathrm{mgg}^{-1}\right)$ is the Dubinin-Radushkevich constant related to the degree of dye adsorption; $k_{\mathrm{ad}}\left(\mathrm{mol}^{2} \mathrm{~J}^{-2}\right)$ is the Dubinin-Radushkevich isotherm constant related to sorption energy; $\varepsilon$ is known as the Polanyi potential whose value is represented by the following equation:

$\varepsilon=R T \ln \left[1+\frac{1}{C_{\varepsilon}}\right]$

$b_{T}\left(\mathrm{Jgmol}^{-1} \mathrm{mg}^{-1}\right)$ is the Temkin isotherm constant; $A_{T}\left(\mathrm{Lmg}^{-1}\right)$ is the equilibrium binding constant.

The isothermal parameters and the correlation coefficients $\left(\mathbb{R}^{2}\right)$ were summarized at temperatures of $293 \mathrm{~K}, 298 \mathrm{~K}, 303 \mathrm{~K}, 313 \mathrm{~K}$ and $323 \mathrm{~K}$ for $\mathrm{CS} / \mathrm{CoFe}_{2} \mathrm{O}_{4}$ and at $323 \mathrm{~K}$ for naked $\mathrm{CoFe}_{2} \mathrm{O}_{4}$. The non-linear plots of the isotherm models are shown in Figure 11 ((a)-(f)). It can be seen from Table 2 that the Langmuir isotherm has better conformity with the experimental data due to the correlation coefficient, $\mathrm{R}^{2}$, higher than 0.995, indicating that the AY17 dye uptake takes place on a homogeneous adsorbent by monolayer coverage without any interaction between AY17 anions. The calculated value for maximum adsorption capacity, $q_{m}$, of $\mathrm{CS} / \mathrm{CoFe}_{2} \mathrm{O}_{4}$ increases from $51.98 \mathrm{mg} \mathrm{g}^{-1}$ to $89.10 \mathrm{mg} \mathrm{g}^{-1}$ with increasing temperature from $293 \mathrm{~K}$ to $323 \mathrm{~K}$ (Table 2). Therefore, higher temperature is beneficial to the adsorption process. In the last two columns of Table 2, the $q_{m}$ values of $\mathrm{CS} / \mathrm{CoFe}_{2} \mathrm{O}_{4}$ and naked $\mathrm{CoFe}_{2} \mathrm{O}_{4}$, obtained from the Langmuir model, were compared under the same experimental conditions. The $q_{m}$ of $\mathrm{CS} / \mathrm{CoFe}_{2} \mathrm{O}_{4}$ at $323 \mathrm{~K}$ and $\mathrm{pH}=4.0$ is 89.10 , which is $226 \%$ higher than that of naked $\mathrm{CoFe}_{2} \mathrm{O}_{4}, 27.31 \mathrm{mg} \mathrm{g}^{-1}$. The result shows that the coating of $\mathrm{CoFe}_{2} \mathrm{O}_{4}$ with chitosan (which has plenty of hydroxyl and amino groups on the chain to connect to dye anions) remarkably improves its affinity to AY17.

The feasibility of the adsorption process is determined by a dimensionless constant separation factor, $R_{E}$, which is given as:

$R_{L}=\frac{1}{1+K_{L} C_{0}}$

where $K_{L}\left(\mathrm{~L} \mathrm{mg}^{-1}\right)$ is the Langmuir equilibrium constant, $C_{0}$ is the highest initial concentration of dye. $R_{L}$ values between 0 and 1 imply a desirable process, values larger than 1 are an indication of an unfavorable isotherm, and values equal to zero point out a totally irreversible isotherm. ${ }^{41}$ For AY17 uptake onto $\mathrm{CS} / \mathrm{CoFe}_{2} \mathrm{O}_{4}$, the separation factors, $R_{L}$, are less than 0.1 (Table 2). It is obvious that adsorption under the studied conditions is favorable.

\section{Adsorption thermodynamics}

The adsorption thermodynamic parameters, including changes in standard Gibb's free energy $\left(\Delta G^{\circ}, \mathrm{J} \mathrm{mol}^{-1}\right)$, enthalpy $\left(\Delta H^{\circ}, \mathrm{J} \mathrm{mol}^{-1}\right)$ and entropy $\left(\Delta S^{\star}, \mathrm{J} \mathrm{mol}^{-1} \mathrm{~K}^{-1}\right)$, for the adsorption of AY17 onto $\mathrm{CS} / \mathrm{CoFe}_{2} \mathrm{O}_{4}$ were calculated using classical Equations (9) and (10):

$\Delta G^{\circ}=\Delta H^{2}-T \Delta S^{\circ}$

$\Delta G^{\circ}=-R T \ln \left(K_{\mathrm{L}}\right)$

where $\mathrm{R}\left(8.314 \mathrm{~J} \mathrm{~mol}^{-1} \mathrm{~K}^{-1}\right)$ is the universal gas constant, $T(\mathrm{~K})$ is the absolute temperature, $K_{L}\left(\mathrm{~L} \mathrm{mg}^{-1}\right)$ is the equilibrium constant obtained from the Langmuir equation and is the Langmuir constant. The values of $\Delta H^{\circ}$ and $\Delta S^{\circ}$ were calculated from the Van't Hoff non-linear plot of $K_{L}$ against $T$. All the thermodynamic parameters are tabulated in Table 3. 
Table 2

Non-linear isothemal parameters for the adsorption of AY17 onto $\mathrm{CS} / \mathrm{CoFe}_{2} \mathrm{O}_{4}$ at various temperatures ${ }^{*}$

\begin{tabular}{|c|c|c|c|c|c|c|c|}
\hline \multirow{3}{*}{ Isotherm models } & \multirow{3}{*}{ Parameters } & \multicolumn{6}{|c|}{$\mathrm{CS} / \mathrm{CoFe} 2 \mathrm{O} 4$} \\
\hline & & \multicolumn{6}{|c|}{ Temperature $(\mathrm{K})$} \\
\hline & & 293 & 298 & 303 & 313 & 323 & 323 \\
\hline Langmuir & $q_{m}\left(\mathrm{mg} \mathrm{g}^{-1}\right)$ & 51.9805 & 56.2245 & 63.1845 & 72.5804 & 89.1014 & 27.3132 \\
\hline & $K_{L}\left(\mathrm{Lmg}^{-1}\right)$ & 0.0795 & 0.0820 & 0.0873 & 0.0947 & 0.1012 & 0.1061 \\
\hline 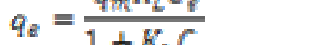 & $R_{2}$ & 0.0949 & 0.0922 & 0.0871 & 0.0809 & 0.0761 & 0.0728 \\
\hline $1+$ & $\mathrm{R}^{2}$ & 0.9996 & 0.9996 & 0.9988 & 0.9997 & 0.9990 & 0.9967 \\
\hline Freundlich & $K_{F}\left(\mathrm{mg}^{1-\frac{1}{n}} \mathrm{~L}^{\frac{1}{n}} \mathrm{~g}^{-1}\right)$ & 7.7770 & 8.443 & 9.7751 & 11.1091 & 11.1147 & 5.8638 \\
\hline$q_{e}=K_{F} C_{\tilde{g}}^{1 / n}$ & $n$ & 2.3611 & 2.3429 & 2.3480 & 2.2599 & 1.8432 & 2.9545 \\
\hline Dubinin-Radushkevich & $q_{s}\left(\mathrm{mgg}^{-1}\right)$ & 40.4226 & $\begin{array}{c}0.9848 \\
43.3696\end{array}$ & $\begin{array}{c}0.9804 \\
49.0375\end{array}$ & $\begin{array}{r}0.9080 \\
55.2929\end{array}$ & $\begin{array}{r}0.9900 \\
66.2438\end{array}$ & $\begin{array}{l}0.9944 \\
23.557\end{array}$ \\
\hline & $k_{a d}\left(\mathrm{~mol}^{2} \mathrm{~kJ}^{-2}\right)$ & 7.2330 & 6.2295 & 5.6944 & 3.9857 & 3.2766 & 8.6862 \\
\hline$q_{e}=q_{1} e^{2}$ & $\mathrm{R}^{2}$ & 0.9809 & 0.9789 & 0.9824 & 0.9770 & 0.9729 & 0.9682 \\
\hline Temkin & $A_{T}\left(\mathrm{~L} \mathrm{mg}^{-1}\right)$ & 1.3967 & 1.4663 & 1.6633 & 2.0433 & 3.7419 & 3.0440 \\
\hline$R T$ & $b_{T}\left(\mathrm{Jg} \mathrm{mol}-1 \mathrm{mg}^{-1}\right)$ & 259.383 & 245.246 & 227.234 & 211.901 & 208.796 & 610.188 \\
\hline$q_{\varphi}=\frac{b_{z}}{b_{5}} \ln A_{T} b_{q}$ & $\mathbb{R}^{2}$ & 0.9907 & 0.9903 & 0.9849 & 0.9846 & 0.9702 & 0.9952 \\
\hline Jovanovic & $9 \mathrm{~m}\left(\mathrm{mg} \mathrm{g}^{-1}\right)$ & 42.8862 & 46.3275 & 51.95 & 59.2165 & 71.6038 & 24.0159 \\
\hline 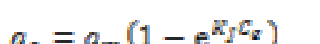 & $K_{I}\left(\mathrm{~L} \mathrm{mg}^{-1}\right)$ & -0.0759 & -0.0784 & -0.0846 & -0.0931 & -0.1017 & -0.0799 \\
\hline$q_{E}$ & $\mathrm{R}^{2}$ & 0.9989 & 0.9989 & 0.9999 & 0.9979 & 0.9974 & 0.9914 \\
\hline
\end{tabular}

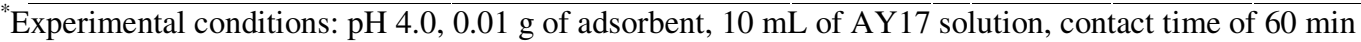

Table 3

Thermodynamic parameters for the adsorption of AY17 onto $\mathrm{CS} / \mathrm{CoFe}_{2} \mathrm{O}_{4}$

\begin{tabular}{|c|c|c|c|c|}
\hline Temperature (K) & $\left.\Delta H(\mathrm{k}\rceil \mathrm{mol}^{-1}\right)$ & $\Delta S\left(\mathrm{~J} \mathrm{~mol}{ }^{-1} \mathrm{~K}^{-1}\right)$ & $T \Delta S\left(\mathrm{k}\left[\mathrm{mol}^{-1}\right)\right.$ & $\left.-\Delta G(\mathrm{k}] \mathrm{mol}^{-1}\right)$ \\
\hline 293 & & & 17.1547 & 10.6610 \\
\hline 298 & & & 17.4473 & 10.9536 \\
\hline 303 & 6.4936 & 58.5183 & 17.7399 & 11.2462 \\
\hline 313 & & & 18.3250 & 11.8314 \\
\hline 323 & & & 18.9102 & 12.4166 \\
\hline
\end{tabular}




\section{HAMIDREZA ANSARI et al.}

The positive value of $\Delta H^{\circ}$ confirmed the endothermic nature of adsorption, which was supported by the fact that the adsorption of AY17 increased at elevated temperatures. The $\Delta H^{\circ}$ value (6.4936 $\mathrm{J} \mathrm{mol}^{-1}$ ) was less than $40 \mathrm{~kJ} \mathrm{~mol}^{-1}$, thereby implying that the adsorption is predominantly physisorption. ${ }^{42}$ The positive values of $\Delta S^{\circ}$ implied an increased randomness at the solid/solution interface during dye uptake,
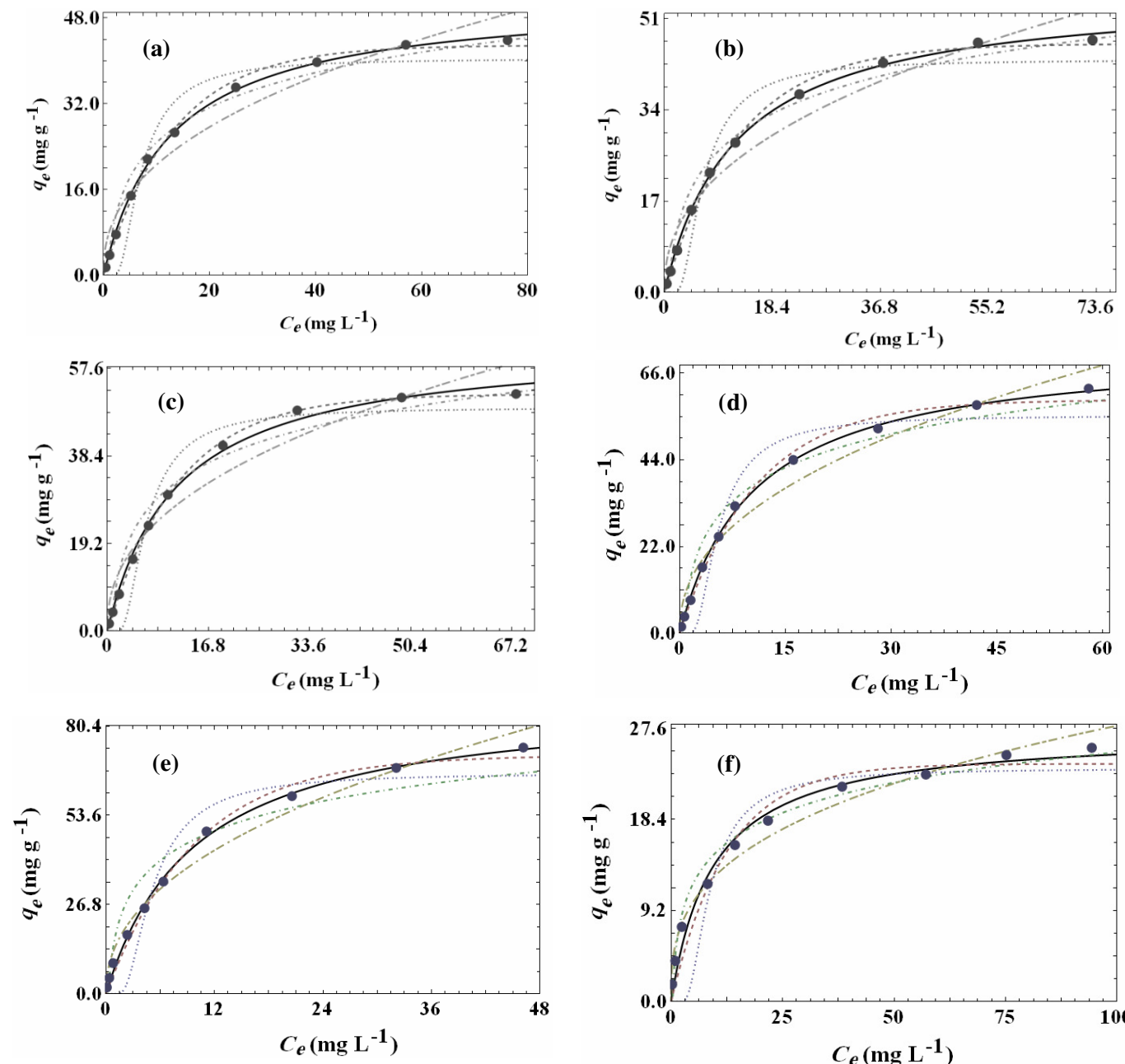

Langmuir,

Dubinian-Radushkevich,

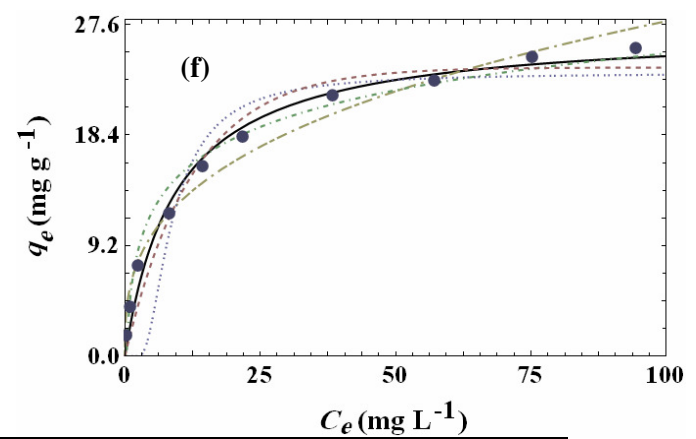

Freundlich,

Tempkin, -............Jovanovic

Figure 11: Non-linear plots of isotherm models for the adsorption of AY17 onto CS/CoFe $\mathrm{O}_{4}$ at temperatures of (a) 293, (b) 298, (c) 303, (d) 313, (e) $323 \mathrm{~K}$ and onto naked $\mathrm{CoFe}_{2} \mathrm{O}_{4}$ at the temperature of (f) $323 \mathrm{~K}$ (black circles show experimental data; experimental conditions: $\mathrm{pH} 4.0,0.01 \mathrm{~g}$ of $\mathrm{CS} / \mathrm{CoFe}_{2} \mathrm{O}_{4}, 10 \mathrm{~mL}$ of AY17 solution, contact time of $60 \mathrm{~min})$ 


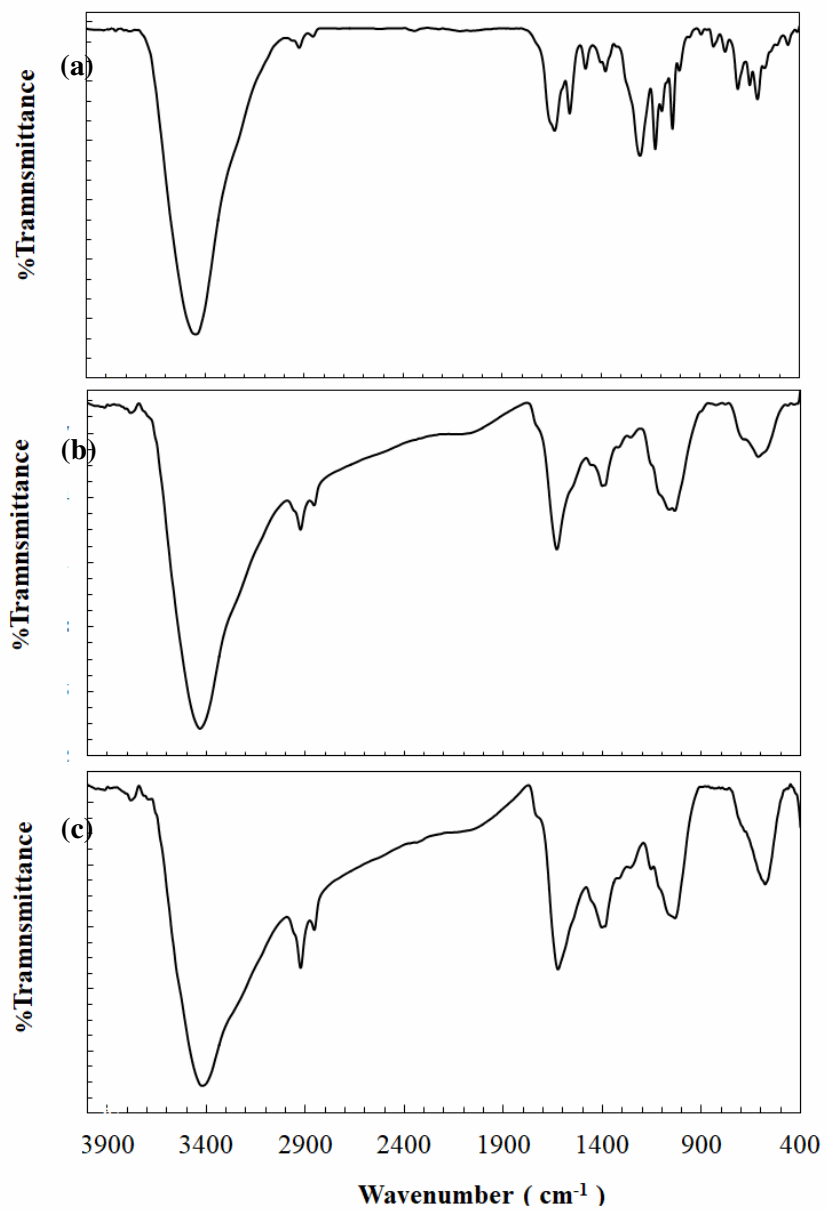

Figure 12: FTIR spectra of AY17 (a) before and (b) after adsorption onto (c) CS/ $/ \mathrm{CoFe}_{2} \mathrm{O}_{4}$

\section{Analysis of adsorption mechanism}

The FTIR analysis was carried out to identify possible active sites on the $\mathrm{CS} / \mathrm{CoFe}_{2} \mathrm{O}_{4}$ magnetic composite for bonding of the AY17 dye. The FTIR spectra of AY17 (a) before and (b) after adsorption are illustrated in Figure 12 (a) and (b), respectively.

The intensity of the strong bands located in the range of $1100-1380 \mathrm{~cm}^{-1}$, attributed to symmetric and asymmetric stretching vibrations of $\mathrm{S}=\mathrm{O}$ of AY17, markedly decreased after adsorption onto $\mathrm{CS} / \mathrm{CoFe}_{2} \mathrm{O}_{4}$ (Fig. 12 (b)), while some peaks entirely disappeared, indicating strong interactions between the $\mathrm{SO}_{3}^{-}$groups of $\mathrm{AY} 17$ with the $\mathrm{N}-\mathrm{H}$ groups of chitosan in $\mathrm{CS} / \mathrm{CoFe}_{2} \mathrm{O}_{4}$. The peak around $3421 \mathrm{~cm}^{-1}$, assigned to the $\mathrm{O}-\mathrm{H}$ and $\mathrm{N}-\mathrm{H}$ stretching vibrations in the FTIR spectrum of $\mathrm{CS} / \mathrm{CoFe}_{2} \mathrm{O}_{4}$ (Fig. 12 (c)), was found to shift to $3433 \mathrm{~cm}^{-1}$ after AY17 adsorption (Fig. 12 (b)). Another change was observed with regard to the peak at $580 \mathrm{~cm}^{-1}$ (Fig. 12 (c)), which shifted toward $604 \mathrm{~cm}^{-1}$ after AY17 adsorption (Fig. 12 (b)), thereby confirming that $\mathrm{CoFe}_{2} \mathrm{O}_{4}$ inside $\mathrm{CS} / \mathrm{CoFe}_{2} \mathrm{O}_{4}$ not only provides effective magnetic separation performance, but also behaves as a binding site for dye adsorption. ${ }^{12}$

Based on the results obtained in this work, electrostatic interactions and the formation of hydrogen bonding are possible mechanisms of dye adsorption onto $\mathrm{CS} / \mathrm{CoFe}_{2} \mathrm{O}_{4}$. Moreover, the pore structure of the adsorbent is beneficial to the diffusion of AY17 anions.

\section{CONCLUSION}

The $\mathrm{CS} / \mathrm{CoFe}_{2} \mathrm{O}_{4}$ magnetic composite was successfully prepared. It possessed excellent adsorption properties for effective removal of a hazardous dye, Acid Yellow 17, and suitable magnetic characteristics, of $21.2 \mathrm{emu} \mathrm{g}^{-1}$, which make the magnetic composite recyclable for further adsorption applications. The pseudosecond order kinetic model with its high 
correlation was appropriate to describe the kinetic process of AY17 uptake onto $\mathrm{CS} / \mathrm{CoFe}_{2} \mathrm{O}_{4}$. The Langmuir model fitted the adsorption data, suggesting the homogeneity of active sites on the surface of $\mathrm{CoFe}_{2} \mathrm{O}_{4} / \mathrm{CS}$. The maximum adsorption capacity of $\mathrm{CS} / \mathrm{CoFe}_{2} \mathrm{O}_{4}$ obtained from the Langmuir model was $89.10 \mathrm{mg} \mathrm{g}^{-1}$ at $323 \mathrm{~K}$, which was much higher than that of naked $\mathrm{CoFe}_{2} \mathrm{O}_{4}, 27.31 \mathrm{mg} \mathrm{g} \mathrm{g}^{-1}$. Based on the thermodynamic parameters, the adsorption process was a spontaneous, favorable and endothermic process in nature.

\section{REFERENCES}

1 M. T. Yagub, T. K. Sen, S. Afroze and H. M. Ang, Adv. Colloid Interface Sci., 209, 172 (2014), https://doi.org/10.1016/j.cis.2014.04.002

2 V. K. Gupta and Suhas, J. Environ. Manage., 90, 2313

(2009),

https://doi.org/10.1016/j.jenvman.2008.11.017

3 K. A. Adegoke and O. S. Bello, Water Resour. Ind., $\quad \mathbf{1 2}, \quad 8 \quad$ (2015), https://doi.org/10.1016/j.wri.2015.09.002

4 K. B. Tan, M. Vakili, B. A. Horri, P. E. Poh, A. Z. Abdullah et al., Sep. Purif. Technol., 150, 229 (2015), https://doi.org/10.1016/j.seppur.2015.07.009

H. Fallah Moafi, R. Ansari and S. Sadeghinia, Cellulose Chem. Technol., 52, 271 (2018), http://www.cellulosechemtechnol.ro/pdf/CCT34(2018)/p.271-282.pdf

6 V. S. Munagapati and D.-S. Kim, Ecotoxicol. Environ. Saf., 141, $226 \quad$ (2017), https://doi.org/10.1016/j.ecoenv.2017.03.036

7 K. K. Kefeni, B. B. Mamba and T. A. M. Msagati, Sep. Purif. Technol., 188, $399 \quad$ (2017), https://doi.org/10.1016/j.seppur.2017.07.015

8 R. Sivashankar, A. B. Sathya, K. Vasantharaj and V. Sivasubramanian, Environ. Nanotechnol. Monit. Manag., $\quad 1, \quad 36 \quad$ (2014), https://doi.org/10.1016/j.enmm.2014.06.001

9 X. Zhao, L. Lv, W. Zhang, S. Zhang and Q. Zhang, Chem. Eng. J., 170, $381 \quad$ (2011), https://doi.org/10.1016/j.cej.2011.02.071

10 D. H. K. Reddy and S.-M. Lee, Adv. Colloid Interface Sci., 201-202, 68 (2013), https://doi.org/10.1016/j.cis.2013.10.002

11 A. Z. M. Badruddoza, Z. B. Z. Shawon, W. J. D. Tay, K. Hidajat and M. S. Uddin, Carbohyd. Polym., 91 322

(2013),

https://doi.org/10.1016/j.carbpol.2012.08.030

12 X. Li, H. Lu, Y. Zhang, F. He, L. Jing et al., Appl. $\begin{array}{lllll}\text { Surf. } & \text { Sci., } & 389, & 567 & \text { (2016), }\end{array}$ https://doi.org/10.1016/j.apsusc.2016.07.162

13 Y. Zhang, T. Yan, L. Yan, X. Guo, L. Cui et al., J. Mol. Liq., $\quad$ 198, $381 \quad$ (2014), https://doi.org/10.1016/j.molliq.2014.07.043

14 C. Ren, X. Ding, H. Fu, C. Meng, W. Li et al., RSC
$A d v .$, 6, 72479 (2016), DOI: 10.1039/C6RA13304E

15 A. S. K. Kumar and S.-J. Jiang, J. Environ. Chem. Eng., 4, 1698 (2016), https://doi.org/10.1016/j.jece.2016.02.035

16 L. Wang, J. Li, Y. Wang, L. Zhao and Q. Jiang, Chem. Eng. J., 181, 72 (2012), https://doi.org/10.1016/j.cej.2011.10.088

17 C. Fan, K. Li, J. Li, D. Ying, Y. Wang et al., J. Hazard. Mater., 326, $211 \quad$ (2017), https://doi.org/10.1016/j.jhazmat.2016.12.036

18 C. Santhosh, P. Kollu, S. Felix, V. Velmurugan, S. K. Jeong et al., RSC Adv., 5, 28965 (2015), DOI: 10.1039/C5RA02905H

19 L. Zhou, L. Ji, P.-C. Ma, Y. Shao, H. Zhang et al., J. Hazard. Mater., 265, 104 (2014), https://doi.org/10.1016/j.jhazmat.2013.11.058

20 N. A. Kalkan, S. Aksoy, E. A. Aksoy and N. Hasirci, J. Appl. Polym. Sci., 124, 576 (2012), https://doi.org/10.1002/app.34986

21 Y. Xiao, H. Liang and Z. Wang, Mater. Res. Bull., 48, $3910 \quad$ (2013), https://doi.org/10.1016/j.materresbull.2013.05.099

${ }^{22}$ H. Zhu, Y. Fu, R. Jiang, J. Yao, L. Liu et al., Appl. Surf. Sci., $\quad \mathbf{2 8 5}, \quad 865 \quad$ (2013), https://doi.org/10.1016/j.apsusc.2013.09.003

${ }^{23}$ L. Zhou, J. Jin, Z. Liu, X. Liang and C. Shang, J. Hazard. Mater., 185, $1045 \quad$ (2011), https://doi.org/10.1016/j.jhazmat.2010.10.012

24 M. Ashrafi, M. Arab Chamjangali, G. Bagherian and N. Goudarzi, Spectrochim. Acta Part A Mol. Biomol. Spectrosc., 171, 268 (2017), https://doi.org/10.1016/j.saa.2016.07.049

25 N. A. Travlou, G. Z. Kyzas, N. K. Lazaridis and E. A. Deliyanni, Langmuir, 29, 1657 (2013), https://doi.org/10.1021/la304696y

26 S. Hajati, M. Ghaedi, F. Karimi, B. Barazesh, R. Sahraei et al., J. Ind. Eng. Chem., 20, 564 (2014), https://doi.org/10.1016/j.jiec.2013.05.015

27 S. Yavari, N. M. Mahmodi, P. Teymouri, B. Shahmoradi and A. Maleki, J. Taiwan Inst. Chem. Eng., $\quad$ 59, $320 \quad$ (2016), https://doi.org/10.1016/j.jtice.2015.08.011

28 O. A. Oyetade, V. O. Nyamori, B. S. Martincigh and S. B. Jonnalagadda, RSC Adv., 5, 22724 (2015), DOI: $10.1039 / C 4 R A 15446 K$

29 R. Sahraei, K. Hemmati and M. Ghaemy, RSC $A d v .$, 6, 72487 (2016), DOI: 10.1039/C6RA12934J

30 S. Lagergren, Sven. Veten. Handl., 24, 1 (1898).

31 Y. Ho and G. McKay, Process Biochem., 34, 451 (1999) https://doi.org/10.1016/S00329592(98)00112-5

32 J. C. Weber and W. J. Morris, J. Sanit. Eng. Div., 89, 31 (1963).

33 S. H. Chien and W. R. Clayton, Soil Sci. Soc. Am. J., 44, 265 (1980), doi:10.2136/sssaj1980.03615995004400020013x 34 G. Limousin, J.-P. Gaudet, L. Charlet, S. Szenknect, V. Barthès et al., Appl. Geochem., 22, 249 
Composites

(2007),

https://doi.org/10.1016/j.apgeochem.2006.09.010

35 F. Deniz and S. D. Saygideger, Bioresour.

Technol., $\quad$ 101, $\quad 5137 \quad$ (2010), https://doi.org/10.1016/j.biortech.2010.02.004

36 I. Langmuir, J. Am. Chem. Soc., 40, 1361 (1918), https://doi.org/10.1021/ja02242a004

37 H. M. F. Freundlich, Z. Phys. Chem., 57, 385 (1906).

38 L. V. Dubinin and M. M. Radushkevich, Proc. Acad. Sci. USSR Phys. Chem. Sect., 55, 331 (1947).

39 V. Temkin and M. I. Pyzhev, Acta Phys. Chim. USSR, 12, 327 (1940)

40 D. S. Jovanović, Kolloid-Zeitschrift Zeitschrift für
Polym, 235, 1203 https://doi.org/10.1007/BF01542530

${ }^{41}$ M. Ignat, V. Dulman and T. Onofrei, Cellulose Chem. Technol., 46, $357 \quad$ (2012), http://www.cellulosechemtechnol.ro/pdf/CCT56(2012)/p.357-367.pdf

F. Shakib, A. Dadvand Koohi and A. Kamran Pirzaman, Water Sci. Technol., 75, 1932 (2017), https://doi.org/10.2166/wst.2017.077

43 D. Suteu, T. Malutan and D. Bilba, Cellulose Chem. Technol., 45, 413 (2011), http://www.cellulosechemtechnol.ro/pdf/CCT45,56(2011)/p.413-420.pdf 